\title{
The politics of reforms in Bismarckian welfare systems
}

\section{Bruno Palier}

Summary: Countries that share a particular social protection system, of Bismarckian inspiration and based on social insurance, seem to encounter similar and particularly awkward difficulties. They also seem to be following parallel trends in reforms, with respect to both their timing and their content and process. This paper is an attempt to compare the development of Bismarckian welfare systems during the last 25 years, showing the common pattern of reform.

'Welfare States in Transition' (Esping-Andersen, 1996), 'Recasting European Welfare States' (Ferrera and Rhodes, 2000), 'Welfare State Futures' (Leibfried, 2000), 'The Survival of the European Welfare State' (Kuhnle, 2000), 'From vulnerabilities to competitiveness' (subtitle of Scharpf and Schmidt (eds.) 2000), 'The New Politics of the Welfare State' (Pierson 2001a), 'Global Capital, Political Institutions, and Policy Change in Developed Welfare States', (Swank, 2002) - these are among the most important recent publications on the welfare state. Their titles indicate that the focus of the academic agenda has now moved beyond the crisis of the welfare state, and towards an analysis of actual social policy changes that have occurred during the last 20 to 25 years. While during the 1980s, attention centred firstly (following the OECD, the new right or Marxist authors) on analysing welfare state crisis, and then (following Titmuss and Esping-Andersen's work) on understanding the differences between welfare states, the key preoccupation is now the analysis and understanding of welfare reforms. In pursuit of this objective, recent comparisons of welfare state reforms have either analysed all types of welfare regimes, or instead focused on the liberal or Nordic regimes specifically. But to date no systematic comparative research has been conducted on the recent developments of the Bismarckian, "conservative corporatist" welfare regimes that are mainly based on social insurance mechanisms.

Despite an absence of systematic comparison within the Bismarckian family of welfare systems, the general literature on welfare state change paints a specific picture of these systems' development, based on the contrasts with other regimes. In this perspective, the general literature usually concludes that, despite the fact that they are facing the biggest challenges, and are the most in need of transformation, Bismarckian welfare systems have proved almost wholly incapable of implementing important reforms.

In this paper, a review of the current literature on welfare state change is confronted to some preliminary findings on actual developments in Bismarckian welfare systems in recent years (part 1). The literature review will draw attention to the lack of systematic comparative research on the development of Bismarckian welfare systems. Juxtaposing the literature to existing - but currently dispersed - analyses of welfare reforms in Bismarckian welfare systems highlights the need to systematise an approach sensitive to the impact of welfare institutions on both difficulties encountered and reforms adopted (Part two). The dominant interpretation of the situation in Bismarckian welfare systems is then questioned with reference to evidence showing that more reforms have occurred - and are occurring - within such systems than is usually recognised. This discussion points, it is argued, to the necessity to identify, measure and differentiate among welfare state changes (Part three). Once they have been identified and compared, the reforms can be analysed as a chain of various types of reforms, the previous one being a pre-condition for the following one; The comparison of welfare reforms in Continental Europe shows the existence of a common trajectory among bismarckien welfare systems, and highlights the importance of sequencing reforms in the understanding of how Bismarckian welafer systems have changed (Part four). 
A fifth part is still there, in italics, proposing some explanation for these trends, to check with you whether it should be kept (and other part reduced, or removed.

\section{How to characterise the Bismarckian world of welfare capitalism?}

Comparisons of welfare state reforms that have been carried out recently have almost all been framed by Esping-Andersen's seminal typology of welfare capitalism. EspingAndersen sought to compare and classify the various types of social protection systems existing in industrialised countries, which may be distinguished both by their underlying value systems and their institutional configuration. This typology is based principally on the effects of social policies, which are taken to reflect the ideological options adopted, and as a result the names given to these systems reflect their underlying ideological concepts. Esping-Andersen thus distinguishes between three types of social protection systems: the social democratic, the conservative-corporatist and the liberal.

There has been continuous debate about the Esping-Andersen typology (for reviews see e.g. Abrahamson, 2003; Arts and Gelissen, 2002). Despite a number of criticisms, it seems that recent research on welfare reforms inevitably comes back to this three-fold distinction. Indeed, most collective books either refer to the 'three worlds' in their choice of countries (see Scharpf and Schmidt, 2000 or Pierson, 2001), or organise the comparison explicitly through groups of countries that reproduce this division (see Esping-Andersen, 1996 or Sykes, Palier and Prior, 2001). Moreover, findings usually suggest that there are 'three worlds of welfare reforms', with comparative studies concluding that there are different processes of welfare state adaptation that can be associated with each world of welfare (Scharpf and Schmidt 2000; Pierson 2001b). The three paths for welfare state change result from the three different contexts of historical and institutional constraints in each welfare system. Scharpf and Schmidt (2000) convincingly show that the three worlds do not experience the same kinds of vulnerabilities in the face of the new global and European environment. Examining the implementation of several policies, Pierson proposes that besides cost containment which is common to all welfare reforms - a specific type of reform is predominantly pursued in each world of welfare capitalism: 're-commodification' in the liberal welfare states, 'rationalising re-calibration' in the Nordic countries and 'up-dating recalibration' of the Continental systems (Pierson, 2001b: 455).

The findings of recent research have led to the conclusion that reforms had a limited impact on the structure of the different welfare states, not threatening but instead preserving and even reinforcing the very nature of each system. Thus, due to various processes of marketisation in social protection, and the re-commodification strategy adopted, liberal welfare states have become even more residual and liberal (Taylor-Gooby, 2001). Social democratic welfare states, thanks to an egalitarian distribution of cuts (around 10 per cent across all benefits) and a rediscovery of 'the workline', are similarly returning to their traditional road to welfare (Kuhnle 2000, Revue française des affaires sociales, 2003). And, from the point of view of much comparative research, most of the continental welfare states have remained essentially the same, not only because reforms have reinforced their characteristics, but also because of an apparent inability to implement any substantial reform at all (giving rise to terms such as 'eurosclerosis or 'frozen fordism').

However, the research that has been conducted to date has either included all types of welfare regimes ${ }^{1}$, or focused on liberal $^{2}$ or Scandinavian regimes ${ }^{3}$. No systematic

\footnotetext{
${ }^{1}$ ESPING-ANDERSEN, Gøsta (ed.), 1996, Welfare States in Transition, National Adaptations in Global Economies, London, Sage; FERRERA, Maurizio, RHODES, Martin (eds.), 2000, Recasting European Welfare States, West European Politics (Special Issue), April; LEIBFRIED, Stephan (ed.), 2001, The Future of the Welfare State, Cambridge University press; PIERSON, Paul, (ed.), 2001, The New Politics of the Welfare State,
} 
comparative research has been conducted on the recent developments of Bismarckian, 'conservative corporatist' welfare regimes. One can only find isolated national case studies, for example on the Netherlands (Hemerijck and Visser, 1997), Italy (Ferrera and Gualmini, 2004), France (Palier, 2002) or Germany (Seeleib-Kaiser, 2004).

The aim of this paper is to propose a framework for a systematic comparison of welfare reforms within the 'conservative corporatist' world of welfare capitalism, with the idea that more has occurred within these systems than is usually recognised. Here, we will focus on reforms to existing social policies and the introduction of new types of social policies in welfare systems and specific social programmes that share the common features usually associated with the Bismarckian tradition of social insurance, or the 'conservative corporatist' world of welfare capitalism.

These features have already been characterised in the comparative welfare state literature. Esping-Andersen and others have identified three main approaches to the conception, implementation and management of social protection mechanisms ${ }^{4}$. Instead of trying to read Esping-Andersen's typology as a description of the 'real worlds' of welfare capitalism, it is useful to conceptualise it as isolating distinguishing ideal-types, differentiated both in terms of policy goals (logic or conception) and policy instruments ('ways of doing', institutions). These ideal types define a body of principles, values and political, economic and social objectives that can be associated with a prevailing institutional configuration that determines the rights and benefits, the financing and the management of the social protection of individuals resident in a nation. They also help to identify the role and position given to social protection institutions in relation to other factors of social protection (the market, the family and the voluntary sector), as well as the objectives pursued (and achieved) in terms of individual welfare and changes in social stratification. Such ideal-typical categories can help to situate the core features of any real welfare system, or even any welfare programme, notwithstanding the complexities which inevitably characterise any empirical reality.

In terms of policy goals, one can identify three political logics in Esping-Andersen's work: the liberal, the social-democratic, and the conservative-corporatist. The presentation of these logics can be supplemented by a review of the gender relationships dominating in these three models (Lewis, 1992, Orloff, 1993), and of the relationship between the voluntary sector and the State under these various configurations (Sarasa, 1995).

Oxford: Oxford University Press; SCHARPF, Fritz W., SCHMIDT, Vivien A., (eds.), 2000, From Vulnerability to competiveness: Welfare and Work in the Open Economy, Oxford: Oxford University Press, 2 volumes; SYKES, Rob S., PRIOR, Pauline, PALIER, Bruno (eds.), 2001, Globalization and European Welfare states : challenges and changes, Londres : Macmillan; TAYLOR-GOOBY, Peter (ed.), 2001, Welfare States Under Pressure, Londres, Sage STEPHENS, john D., HUBER, Evelyne, 2002, Development and crisis of the welfare state : parties and policies in global markets, Chicago : University of Chicago Press; SWANK, D., 2002, Global Capital, Political Institutions, and Policy Change in Developed Welfare States, Cambridge, Cambridge University Press; WILENSKY, Harold, 2002, Rich Democracies: Political Economy, Public Policy, and Performance, University of California Press.

2 See for instance: PIERSON, Paul, 1994, Dismantling the Welfare State? Reagan, Thatcher and The Politics of Retrenchment, Cambridge, Cambridge University Press; Ann Orloff, Julia O'Connor, Sheila Shaver, 1999 States, Markets, Families: Gender, Liberalism and Social Policy in Australia, Canada, Great Britain, and the United States, New York, Cambridge, and Melbourne: Cambridge University Press.

${ }^{3}$ Kautto, M., J. Fritzell, B. Hvinden, J. Kvist \& H. Uusitalo (eds.) 2001. Nordic Welfare States in the European Context. London: Routledge ; Revue française des affaires sociales, " modèle nordique ", 2003.

${ }^{4}$ Esping-Andresen uses three criteria to differentiate the three worlds of welfare capitalism: the level of decommodification achieved by social protection systems; the relationship between the institutional configuration and the various forms of social stratification; and the relationship between the state, the market and the family. 
The so-called "conservative-corporatist" model, that we may want to re-name "categorial" or "Bismarckian" model, organised on the basis of occupational categories, is designed much less to reduce inequality than to provide workers with security, and to conserve status. The level of social protection offered to each beneficiary is determined by market performance and employment situation. As a result of the relatively generous level of the social benefits provided, it also guarantees insured individuals a certain level of independence in relation to the market in the event of a contingency. In this case, dependence on the market is indirect in so far as the level of social benefits provided by these systems is itself related to prior employment (and family situation). The universality of coverage is therefore dependent on the capacity of society to ensure full employment. This model is frequently associated with a family structure based on the male breadwinner, which implies that women are left with prime responsibility for caring (Lewis, 1992). Under this model, the participation of women in the labour market is fairly low (France being an exception). Voluntary associations are organised on an ideological or religious basis and maintain neo-corporatist relations with the state under the principle of subsidiarity. They organise social services supported by public financing. These associative groups exercise a major influence over the social policies adopted by the state.

To achieve their objectives, the various systems make use of a range of techniques (means-tested assistance benefits, contributory benefits provided by social insurance on the basis of social contributions in bismarckien ones, social services or flat-rate benefits). In order to be able to identify and compare specific ways of providing welfare - which will henceforth be referred to as "welfare institutions" - one can distinguish four principal parameters by which public social protection systems can be differentiated (cf. Ferrera, 1996, who was the first to spell these dimensions out, before they were taken up and developed further notably by Bonoli and Palier, 1998):

(1) the rules and criteria governing eligibility and entitlement: who is entitled to the benefit?

(2) the forms taken by the benefits: what types of benefits are provided?

(3) financing systems: who pays and how?

(4) the organisation and management of the scheme: who decides and who manages?

We will here analyse and compare reforms that occurred in countries where welfare systems are mainly based on the "categorial" approach of welfare, and where the welfare institutions are mainly based on entitlements associated with employment status, contributory benefits, financing through social contribution and management of the systems by funds ("Kassen”, “caisses”, “caza”...) that are more or less independent from the state. Our basic hypothesis is that the similarity of welfare conception and institutions partly explains the similarities in the problem profile and in the trajectories of these welfare systems. This type of welfare system is found mostly in Continental Europe. Indeed, most countries of the European continent, having followed the Bismarckian route of welfare state development, can be considered as 'social insurance states' and share common features: access to benefits are linked to work position (instead of citizenship or need), most of the benefits are in cash and contributory (instead of flat-reate benefits or social services), much of their social outlays are financed via earnings-related contributions (instead of taxation) and they have established a more or less 'corporatist' management of their schemes (not directly run by the state - this is the term 'welfare system' is more appropriate than 'welfare state' when characterising them).

The comparative welfare state literature has shown that Germany, Austria, France, Netherlands, Luxembourg, Italy, Spain, Belgium, Hungary or Czech Republic have developed welfare systems that are the closest to this ideal-type (Germany usually being the reference 
case). In suggesting that these countries share a logic is mostly or mainly Bismarckian, and institutions mostly or mainly based on social insurance, it should be emphasised and acknowledged that any real welfare system is never pure, and thus represents a complex mix of policy goals and institutions. Of course, family policies in France are of universalist inspiration, the health care system in Italy is a national health care system of Beveridgean inspiration, and Italian trade unions do not play there an important role in the management of the system etc. However, all these countries are closer to each other than to other welfare systems (such as the Swedish or the British ones). The French welfare system is certainly not identical to the Germany one, but it is considerably closer to the German than to the Swedish system, and thus reflect both similar principles of welfare and comparable 'ways of doing' welfare. Therefore, the French and German systems should also experience some similar difficulties and some similar reform dynamics.

We identify welfare institutions that Bismarckian welfare systems have to a greater or lesser extent in common as a central variable for identifying and understanding the politics of recent welfare reforms.

\section{The importance of welfare institutions}

In the literature, three different phases of the development of the welfare state are commonly identified. A first period of emergence of welfare states (nineteenth century to second world war) was succeeded by the "golden age of the welfare state, its period of steady growth (from 1945 to the mid 1970s), which was in turn superseded by an era of difficulties. This last period is that in which the crisis of the welfare state has been analysed, and when the so-called new politics of the welfare state in a period of permanent austerity (Pierson, 1998, 2001) emerged; others have referred to the 'silver age' of the welfare state (Tayor-Gooby). In fact, this last period is perhaps more accurately divided into two different ones, a 'first third' period being 'the crisis of the welfare state', before a 'second third' period of more intense and creative reform, of 'restructuring' and 'recasting' of the welfare state (Ferrera, Rhodes), and of the search for a 'new architecture' for the welfare state (Esping-Andersen (ed.), 2002). This latter period can be dated from the mid 1980s or early 1990s onwards (with differential timing depending on the country/welfare system, see below). Here, we will more precisely focus on (and distinguish) these two moments of recent ('stage three') welfare state development, that is the crisis of the systems, and their period of reform and change.

The current literature on welfare state change does not focus specifically on Bismarckian welfare regimes, but draws a comparative picture of their development, in contrast with other regimes. When he analysed 'national adaptation in global economies' and compared the various capacities of different welfare regimes to face the new economic challenges, Esping-Andersen emphasised the rigidity of the continental welfare state arrangements, speaking of a 'frozen continental landscape' resulting from the 'frozen Fordism' found in Germany, France or Italy (Esping-Andersen, 1996). He concluded that 'the cards are very much stacked in favour of the welfare state status quo' in these countries (ibid.:267). As mentioned previously, Scharpf and Schmidt (2000) have shown that if all welfare states do present vulnerabilities to the new open economic context, the welfare systems based on social insurance face the biggest difficulties of all welfare states, while Pierson (2001) argues that reforms have been rarest and most problematic in conservative corporatist regimes.

As depicted by the current literature, most of the continental welfare states remain the same, not only because the reforms reinforced their characteristics but also because they seem unable to implement any important reforms. While other welfare regimes have been able to overcome their difficulties through the introduction of reforms inspired by their own tradition 
(see above), Bismarckian welfare systems not only appear unable to find a way out of the crisis in their own traditions, but actually seem to be locked into their difficulties by the very weight of that tradition. How do the literature explain this situation?

Bismarckian welfare systems are said to be both the most challenged by the new economic context and the most frozen of welfare states. Interestingly, when trying to explain why Bismarckian welfare systems face such enormous challenges, authors usually refer to welfare institutional designs, but when trying to understand why reforms are so comprehensively blocked, they neglect these welfare institutions in their explanations, in favour of broader political factors. If the impact of welfare institutions on the specific economic and social problems met in Continental Europe seem indeed important, we will argue that one should also focus on the impact of welfare institutions in order to understand the politics of the reforms implemented.

The most challenged welfare systems: Welfare institutions and new economic and social challenges

The literature on welfare state crisis identified several causes of the welfare state's difficulties since the mid-1970s, including socio-economic challenges such as mass and structural unemployment, population ageing, rising female labour market participation, increasing capital mobility and intensified competition between economies. Though these trends are important everywhere, the literature on welfare state change has shown that they do not impact in exactly the same way on all countries, since they are filtered by welfare institutions. In order to demonstrate why Continental welfare states are the most challenged, a number of analysts refer to the institutional settings of their welfare programs. EspingAndersen (1996) has argued that their difficulties are partly due to the necessity to defend the so-called 'family wage' (thereby excluding the youngest, the oldest and women from the labour market). By family wage one has to understand the status associated with employment: a salary plus all the social benefits associated with it. Here, Esping-Andersen underlines the problem of a system where the social benefits are mostly linked to work, are given to the male breadwinner, and are mainly in cash and contributory. It is thus the type of social benefits delivered in Continental Europe which helps to explain the specificity of the problems these systems face. In a similar perspective to Scharpf and Schmidt (2000, see above), Daly (2001) has shown that the Bismarckian welfare states present three specific pressure points in the face of globalisation: the funding structure and methods for financing (which create problems of labour costs), the highly legitimate nature of the claim structure (which hamper retrenchment), and the lack of flexibility in a cash benefit-based system (which prevent new social risks to be covered).

\section{A frozen landscape?}

Despite the profound difficulties they face, change has until recently been difficult to implement in Bismarckian social protection systems. The current literature on welfare state reforms is highly influenced by Paul Pierson's work. He has convincingly shown that the politics of the welfare state under conditions of austerity are different from the politics of the 'golden age' (Pierson, 1996). In his recent edited volume (2001) Pierson and his colleagues provide insightful institutionalist explanations of the politics of welfare reforms, which focus on the way institutions such as systems of interest intermediation and political structures shape the new politics of reform (Pierson, 2001, part Two and Three). When trying to explain why it is so difficult to reform one has partly to refer to the general political institutions of each country (Bonoli, 2001) as well as to the political orientation of the government (Levy, 
1999 ; Ross, 2000). The variables that are usually mobilised for explaining the reforms or the absence of reforms are usually related to the political system rather than welfare institutions per se.

These variables take very different values within the family of Bismarckian welfare regimes (for example, Germany has a federal political system while France has a highly centralised system). However, one can see similarities in the politics of the reforms. There is considerable evidence that this is a common pattern in all these countries, which has probably, therefore, to be explained by similar variables. Since all these countries do not share the same political system, it is hard to defend the idea that a reference to the political system (e.g. the number and strength of veto players...) can explain why they are - in every case - difficult to reform. To understand the politics of the reforms in these cases, it seems more promising to look at the kind of incentives that their similar welfare state institutions create.

As Bonoli and Palier have shown (2000), welfare institutions structure debates, political preferences and policy choices. They affect the positions of the various actors and groups involved in reform processes. They frame the kind of interests and resources which actors can mobilise in favour of, or against, welfare reforms. In part, they also determine who can and who cannot participate in the political game leading to reforms (the identity and number of veto players). Depending on how these different variables are set, different patterns of support and opposition are likely to be encountered.

Why are Bismarckian welfare systems so frozen? The influence of welfare institutions.

One could thus argue that all the institutional characteristics of the Bismarckian welfare states contribute to its resistance to change: contributory benefits enjoy a particularly high level of legitimacy and are therefore difficult to be cut back radically. Transfers are 'paid' by social contributions, so workers assume that they have 'bought' social rights. Benefits are usually generous, so their loss would be more significant than the reduction of a benefit which is already at a low level. People prefer to pay more (contributions) than seeing their benefits (bought by their own work) diminished. Finally, insurance-based transfers are well defended by organised interests, and in particular by trade unions of the different branches corresponding to the different professional schemes.

In Continental Europe, governments have long preferred to increase social contributions than to cut social benefits. This is counter-intuitive from an Anglo-Saxon (and even a Scandinavian) point of view, where the most politically risky thing to do is to raise taxes, and where the population prefers some cuts in social programmes to any tax increases. These differences are due to the differences in the type of benefits and, moreover, in the way in which they are financed. In Bismarckian countries, most of the cash benefits are contributory, earnings-related benefits. And the bulk of social expenditure is financed through employment related contributions. There is a crucial difference between tax- and contributionfinanced schemes in their ability to attract public support. Whereas taxation goes to the state, social contributions are perceived as a 'differed wage' which will return to the insured person at times of sickness, unemployment or retirement. Paying health insurance contributions, for instance, 'buys' a right to health care which guarantees protection during periods of sickness. From a political point of view, contributions are raised much more easily than taxes, especially income taxes.

On the benefit side, it is more feasible to reduce flat-rate or means tested benefits than earnings-related ones. Since earnings-related benefits are often expressed as a proportion a salary, there is a form of 'automatic' indexation on earnings, which tends to be the most 
generous form of indexation. In the case of contributory benefits, benefits remain constant in terms of replacement rates unless cuts in the benefit formula are adopted. These are highly visible and politically difficult to implement. Moreover, as they are contributory, people think that they have 'bought' their own social benefits through the social contribution they have paid. Therefore, they are not ready to accept a reduction in provision for which they have been working. On the contrary, they are ready to pay more as long as it guarantees a high level of benefit.

Here again, the difference in the financing mechanisms is essential here. Whereas taxation goes to the State, social contributions are perceived as a 'differed wage' which will come back when the insured person is sick, unemployed or aged. Where a Reagan, a Thatcher or a Major could denounce the excessive weight of taxes and the unwarranted cost of the social benefits delivered to those who do nothing, it was much more difficult for continental European politicians to attack social insurance rights acquired by all the working population through the payment of social contributions. Instead of reducing highly legitimate benefits, it was much easier to raise social contributions, as long as it was to preserve the social rights of all workers and families, and the level of their benefits.

Whereas for retrenchment in leiberal welfare regimes, the popiulation targeted was usually weak and not well represented, and whereas in Universal regimes, it wqas the whole population which was concerned by reforms, in Continental Europe, the beneficiaries of social protection susceptible to cuts where well represented and defended by labour unions while the State encountered high difficulties to impose retrnechment policies. In most Bismarckian welfare systems, management is shared with trade unions and employers, responsibility tends thus to be diluted, diminishing the capacity of the state to control the development of the social protection system, and particularly levels of expenditure. Union involvement in the management of social security grants unions a de facto veto power against welfare state reforms (Bonoli and Palier, 1996).

We see that each traits of Bismarckian welfare institution tend to contribute to render welfare retrenchment extremely difficult. However, simply saying that cuts to social insurance benefits are difficult to implement does not tell the whole story of welfare reforms in Continental Europe. More happened - and is happening - in such systems than is usually suggested in the general comparative welfare state literature. The conventional assessment of the frozen landscape in Continental Europe is based on comparison with others, where important reforms have occurred sooner, and where they could be analysed in terms of retrenchment, cuts and quantitative changes. A more subtle view of social policy change is needed in order to grasp all the full range of reforms that have been and are implemented in continental Europe.

\section{Frozen or insufficiently explored landscape? The necessity to differentiate among reforms.}

\section{Is the realm of social insurance so frozen?}

Bismarckian welfare systems have been seen as frozen because few cuts were implemented there during the 1980s and early 1990s, compared to the experience of other countries. However, changes other than retrenchment have been implemented in continental Europe. Reforms with important retrenchment effects in the long run were actually decided in the mid 1990s. Moreover, in the early 2000s, substantial reforms are being planned for social 
protection systems in Continental Europe : the Schröder 2010 Agenda and the various Hartz reforms include sweeping changes in labour market policies, in health insurance as well as in pension; the 2003 Raffarin/Fillon pension reform and the Douste Blazy 2004 health care insurance reform meant profound changes in France; the Berlusconi government intends to enact further pension reforms in Italy; and the Austrian government did negotiate a pension reform in 2002/2003. This new wave of reforms - which is unfolding in a context of economic recession and high unemployment which is particularly preoccupying in Continental Europe tends to contradict the idea that continental Europe is a frozen landscape as far as welfare reform is concerned. One could even show that more reforms occurred sooner than is usually recognised. But in order to see such changes, it is first necessary to change the framework of analysis of welfare reforms, which to date has been overly focused on retrenchment.

Retrenchment seems to have become one of the most common terms employed to describe recent welfare state developments. The notion lends itself to a staged or functionalist model of analysis of the history of welfare states: emergence (late $19^{\text {th }}$ century until 1945 ) is followed by growth (the golden age, mainly until the 1970s) to limits (or even crisis, in the 1980s), and then followed by retrenchment (since the late 1980s). The notion of retrenchment carries the same problems as those of development, modernisation or growth of welfare states. All were criticised for assuming a uniformity of the processes of welfare state development. If all changes which have occurred since the 1980s can be termed retrenchment they would imply shrinking all welfare states. Therefore, in this framework, the main question is often to measure how much retrenchment has been applied, with large or small cuts as the dependent variable and a focus on spending. Yet, a great deal of academic discussion during the 1990s was aimed precisely at demonstrating that even if expenditure levels were similar, different welfare states spent money differently, under different principles, for different purposes and with different institutions (Esping-Andersen 1990). If the lessons of these debates are kept in mind when focusing on recent changes, it should be envisaged that different welfare states are currently changing differently. Even if an increasing number of efforts are being made in that sense (Esping-Andersen 1996; Scharpf and Schmidt 2000; Pierson 2001), there is still a need for a systematic differentiation of processes of retrenchment, different "reform trajectories", as there was a differentiation between welfare states development trajectories during their 'golden age' (Esping-Andersen 1990).

It could be argued that retrenchment is a reductive term because certain changes in some social protection systems might not bring about less generous benefits. As the trente glorieuses could not be analysed merely in terms of 'more' welfare state, current developments are more complex than simply representing 'less'. Firstly, data show that most of the OECD countries have increased their social spending over the last two decades. Already in the early 1990s, Pierson (1994) concluded that, if anything, overall welfare spending had increased over the years he studied. He concluded that government wanted to retrench, but this was made impossible by the political power of those ('programmatic constituencies') defending welfare state, and as a result the present consequences of past commitments. This may be true for liberal welfare states, but another perspective seems more appropriate as far as other welfare systems are concerned. In recognition of the new problems which welfare states were confronting, some governments were in fact willing to spend more rather than less. It seems, at least, that this was the case for many Bismarckian countries in the late 1970s and during the 1980s (Palier 2000; Manow and Seils 2000).

Secondly, for governments the question may not be a quantitative one (of more or less spending), but instead a structural one: how can welfare states be transformed in order to promote new principles and to develop new institutions which are more adapted to the current (economic and social) situation? Accordingly, reforms are not necessarily aimed at benefit levels or access conditions and thus cannot be considered as retrenchment (neither as 
improvement of the generosity of the benefits). Yet they may prove to be extremely important reforms, since they can introduce changes in the very nature of national welfare state systems. In this case, the measurement of change should not be quantitative (in terms of expenditure, benefit levels, scope of coverage, etc.), but should instead provide an assessment of the degree of innovation introduced by changes. Typical questions would be whether reforms introduced new institutions, promoted a new logic or led to the involvement of new actors. Thus, what is needed for our purpose is a framework of analysis which helps to distinguish, identify and assess these kind of changes.

\section{Differentiating between social policy changes}

When emphasising the inertia of institutions ('frozen landscapes' and 'path dependency'), current research often ignores the structural impact which public policies may sometimes have. While integrating phenomena of path dependency in welfare state analysis is essential, this should not prevent us for examining the impact of different reforms on social policy. In other words, recent developments within the social protection systems are not only due to their own evolutionary dynamic, but also about the implementation of public policies. Incorporating public policy aspects of change into the study of the ways in which social protection systems adapt suggests the advantages of making use of the tools of public policy analysis, and particularly of Peter Hall's approach to policy change. An increasing number of scholars are adopting this framework of analysis to promote understanding of social policy reforms, especially in Bismarckian countries (see for instance Visser and Hemerijck, 1997, Palier, 1999, Hinrichs, 2000, Guillemard, 2003).

Elaborating his framework for analysing macro-economic policy changes, Hall (1993) distinguished between three different types of changes ${ }^{5}$. This approach helps to differentiate between the different impact which a reform will have, depending on whether or not it changes the instruments and/or the overall logic. It provides a grid for assessing the type of change beyond a purely quantitative approach (more or less retrenchment) and a means for judging the degree of innovation introduced by a specific reform. A first type of change will not imply profound changes as far as a historical path is concerned. It simply implies a change in the setting of instruments (such as raising the level of social contributions or lowering benefit levels without changing the mode of financing, the type of benefit or the mode of access to it). It does not imply a change in the general principles and logic.

A second type of changes involve the introduction of new instruments (i.e. the introduction of new calculation rules or new entitlement rules in pension). These types of changes appear to be path dependent. Most of them appear to be using new instruments in order to preserve the existing system and its principles. Yet, they may lead to substantial changes once they have been put in place and developed over time ${ }^{6}$. Studies of recent welfare

\footnotetext{
5 'We can identify three distinct kinds of changes in policy... First, [a change of] the levels (or settings) of the basic instruments. We can call the process whereby instrument settings are changed in the light of experience and new knowledge, while the overall goals and instruments of policy remain the same, a process of first order change in policy... When the instruments of policy as well as their settings are altered in response to past experience even though the overall goals of policy remain the same, [changes] might be said to reflect a process of second order change... Simultaneous changes in all three components of policy: the instrument settings, the instruments themselves, and the hierarchy of goals behind policy... occur rarely, but when they do occur as a result of reflection on past experience, we can describe them as instances of third order change' (Hall 1993: 278279).

${ }^{6}$ Myles and Quadagno (1997) illustrate this. Within pension systems, a transition from a defined benefit to a defined contribution scheme implies a change in the mode of pension benefit from deferred wages to savings, for instance.
} 
state changes have mainly, framed by the notion of retrenchment, have mainly identified these two fist types of changes

However, further reforms may introduce new instruments associated with new goals, and thus possibly represent in the long run what Hall has termed 'paradigmatic changes' (Hall refers to the shift from Keynesian to monetarist policies; an equivalent in social policy might be the shift from unemployment compensation to activation policies). Adding to these three categories of changes, Hemerijck and Visser (1997) identify an intermediary type of change between instrumental and paradigmatic change, which they call 'institutional change'. This is when a basic institution of a welfare system is reformed, such as through privatisation of a public service, or a change in the financing mechanism (taxes replacing social contributions, for instance). These institutional reforms are focused on institution themselves, without explicitly mentioning the goals, but usually they also imply a change in social policy goals. Therefore, they could be associated with third order changes, but incremental ones.

Beyond quantitative criteria (more or less spending), it is then possible to distinguish different categories of changes, on the basis of qualitative, but objective, criteria. We can now apply this framework of analysis to the main developments of various welfare reforms, trying to identify the specific trajectory of in Bismarckian welfare systems.

\section{A common trajectory?}

According to existing analyses of national studies (Visser and Hemerijck, 1997; Palier, 1999, Ferrera, Gualmini, 2002; Hinrichs, XXX), it seems possible to hypothesise that Bismarckian welfare systems have been subject to various types of reforms in a rather successive way, thus demonstrating a specific reform trajectory. During the last 25 years, governments from continental Europe have implemented different types of reforms aimed at coping with welfare state problems. They of course tried to reduce the level of social benefits, that is to introduce retrenchment policies, especially during the early 1990s. But, before that, especially between the mid 1970's and the late 1980's, governments followed another policy path, increasing both expenditures and social contributions in order to face increasing social needs. This was 'before retrenchment'. Since the early 1990's, they have also introduced policies aimed at re-structuring the whole welfare system, policies which are going 'beyond retrenchment and introduce institutional reforms. Recently, all government have introduced a second wave of sectoral reforms, aimed at not only retrenching public social insurance benefits, but also at restructuring the systems themselves, multiplying the types and providers of benefits.

\section{Before Retrenchment}

During the late 1970s and the early 1980s, governments in Continental Europe responded to social difficulties mainly by raising the level of social contributions. In recognition of new problems which they were confronting, governments thus spent more, rather than less: In Germany, 'The 80's were not a time of simple retrenchment. Under conditions where neither federal nor state government was obliged to pay the welfare bill, the door was open for increased benefits or expanded entitlements' (Manow and Seils 2000: 279). During the 1980's, while they were decreasing the level of direct income taxation, the French governments were raising the level of social contribution paid by employees. Among taxation, the share of social contribution has increased dramatically (from 39\% in 1970 to 46\% in 1995) as well as their proportion of GDP: in 1978, the volume of social contribution equalled less than 20\% of French GDP, and almost 23\% in 1985 (Palier, 2002). The state was not paying the welfare bill: it was financed by social contributions. 
The increase in social spending in the 1970's and early 1980's can be understood in different ways. In part, governments paid the bill of commitments made in an earlier period (See Pierson, 2001 for such an explanation). But governments, especially in continental Europe, also increased the generosity of social benefits, notably for those who were particularly hard-hit by the economic crisis (redundant industrial workers, lone parents, poor elderly, long-term unemployed...). In particular, many governments developed benefits aimed at removing job seekers from the labour market - such as early retirement schemes and invalidity pensions - implementing what Esping-Andersen called the 'welfare without work' strategy (Esping-Andersen, 1996). The point here is that this policy path appeared feasible since all the related increases in expenditure were offset by politically acceptable increase in social contributions, which occurred repeatedly in these countries during this period. It can be claimed here that during this period, first order changes were implemented in order to cope with the new situation (economic crisis, growing unemployment, deficits in social welfare budgets), with governments using the instruments already available: their policies consisted mainly in increasing the generosity of existing benefits, and in increasing the level of social contributions.

\section{Pressure for retrenchment: the 1990s}

From the early 1990s, a changed context prohibited the continuation of these kinds of policies. Under conditions of economic recession (in the early 1990's), and with the economic constraints of the European Single market and single currency becoming stronger, Continental European governments decided (felt obliged) to opt for retrenchment in the social protection system.

This is when first retrenchments appeared. Reforms were introduced which aimed at reducing the level of social benefits while preserving the logic of a given system. One can refer here to the so-called 'consolidation' reforms implemented in Germany at the end of the 1980s and during the early 1990s, or to the French sectoral reforms, aimed at "rescuing the social security system" (new medical agreements in health care, a new benefit in unemployment insurance and new modes of calculating retirement pensions; cf. Palier, 2000:122-126). One could also refer to the Italian pension reforms of 1991 and 1995, or to similar ones in Spain (included in the Toledo pacts in 1995), and so on.

Such re-calibration reforms introduced new instruments but remained within the traditional (historical and institutional) logic of Bismarckian welfare system. These reforms seem to share certain features, which appear to be related to the specific institutional settings of social insurance welfare systems.

First, the retrenchment reforms were not presented as a means to dismantling the Bismarckian welfare state, but of preserving it, and consolidating it. In the political discourse justifying the reforms, one heard that if reform was necessary, it was not because the system was dysfunctional, but because it was suffering the ill-effects of the current situation, where resources were decreasing (because of economic slow down, unemployment...) and spending was increasing (because of unemployment, aging, new social demands...). Since it no longer appeared possible to further increase resources, governments had to retrench (a bit). This discourse can be understood if one remembers the high legitimacy of the benefits delivered by this kind of social insurance systems and the strong attachment of the population to them. These reforms were not made in the name of criticisms of welfare redistribution, but in the name of the crucial necessity to restore their viability.

Second, such reforms were usually negotiated, often between different political parties, and almost always with social partners (for pension, See Schludi, 2004). This can be understood as a consequence of the participation of the social partners in the management of 
social insurance schemes. Since the systems are financed through social contributions levied on wages (and not through taxation), the representatives of those who pay to and benefits from the systems are central players in the political game concerning social policy reforms (Bonoli, Palier, 1996). They have a say in the process of the reforms, and have the power to eventually block them if they do not agree. Here, the role of these veto players should be less understood with reference to the general political institutions than with reference to the welfare state design. Indeed, France is far from being a consensual political system; however, as in other Bismarckian systems, no social policy reforms could be passed in France without (at least implicit) agreement of (at least a majority of) the social partners.

Third, the main technique used to reduce welfare benefits in these reforms was to increase the 'contributivity' of the benefits, i.e. strengthening the link between the amount of contribution and the volume of the benefits (through a change in the calculation formula and/or stricter entitlement rules). This of course relied on the already existing logic of these social insurance schemes (where one gets the right to social benefits by paying social contribution), even though these reforms usually meant a shift from redistribution (horizontal and vertical) to actuarial principles.

Finally, the acceptance by social partners of these decreases in benefits were usually based on a quid pro quo (Bonoli, 2001), based on the distinction between what should be financed through contribution and what should be financed through taxation. Retrenchments in social insurance programs are often accompanied by a clarification of responsibility, the government proposing to the social partners to assume the financing of non-contributory benefits (flat rate social minima for the elderly, the handicapped, the long-term unemployed; crediting of contributions for period out of work because of unemployment, child rearing...) in exchange of the decrease of social insurance benefits.

These changes have been based on new instruments (changes in calculation rules, shift from defined benefits to defined contribution systems, creation of new state subsidies...), but were perceived as preserving the very nature of social insurance, and sometimes even at reinforcing it (the social partners, for example, often think that making the state pay for non contributory benefits help to 'purify' and thus reinforce social insurance). They do not really challenge the principles of social insurance and can be considered as second order changes.

Beyond retrenchment: institutional reforms

However, since the early 1990's, the welfare systems that are based on social insurance have been increasingly perceived as exacerbating economic, social and political difficulties. Before retrenchment, social insurance benefits were used as a support for the victims of the crisis (compensation) and as a tool to counter it (reflation policies, welfare without work strategies). In the following period, when continuous increase in social spending appeared to be unaffordable, retrenchments were attempted, but essentially to save social insurance, which was perceived as to be the victim of the crisis (less resources, more expenses). In the analyses supporting further and deeper reforms, the systems have become part of the cause of the crisis. In France, for example, social insurance has been accused of partly causing a number of economic, social and political problems: the contributory nature of most social benefits was accused of reinforcing social exclusion; the weight of social contribution of hindering competitiveness and preventing job creation; the participation of social partners in the systems of weakening the state capacity to control expenditure and to implement reforms (Palier, 200, 2002). One can see here that in the recent analyses of the problems met by Bismarckian welfare systems, the causes of the difficulties seem to be the very characteristics of these systems themselves (contributory benefits, financed by social 
contribution, managed by the social partners). If it is the case, they should not only be retrenched, but also profoundly transformed.

It is, then, not only social scientists who acknowledge the impact of institutions on problems, and their role in shaping, and sometimes preventing, change. Through learning processes, experts and politicians have also come to recognise these effects - and sometimes therefore to decide on changes to the institutions. In most of the social insurance welfare systems, (some) structural changes are taking place in order to face these structural difficulties.

In order to cope with new social problems that social insurance is unable to deal with, governments have developed new social policy instruments, with reference to new social policy goals. Faced with the growing amount of jobless, youth or long-term unemployed and lone parents, new benefits have been created, or former marginal benefits have been developed: these are targeted flat-rate benefits, usually financed by taxation and run by the state. Governments have also started to develop more active labour market policies (Clegg, $\mathrm{XXX)}$. In order to cope with uncontrolled increase of health expenditure, the level of public coverage has been reduced, leaving more room for private insurance (Palier, 2003, Wendt, $\mathrm{XXX}$ ). In order to cope with demographic ageing, pension reforms have introduced small private top ups, voluntary and pre-funded pensions over above PAYG mandatory pension (Bonoli, XXX). In all cases, the coverage by social insurance (both in terms of generosity and of universality) is diminishing, leaving room for other types of social policy instruments, but also goals.

Besides change in benefits, some other basic pillars of social insurance are reformed/transformed: contribution financing and the involvement of the social partners in the management of social security. Some recent reforms have been aimed at modifying these institutional arrangements (financing and the management of social security). This is certainly the case in France with the increase of exemptions for social contributions, as well as the development of a new tax to finance non-contributory social benefits (CSG); and with the empowerment of Parliament in the social policy-making process (Palier 2000, 2001). One could also mention reforms introduced in other Bismarckian countries (for example, the introduction of a 'green tax' in Germany to replace some social contribution funding, or the introduction of private employment services in the Netherlands). These institutional reforms introduce new instruments that are usually linked to another logic of welfare (taxation, public or private management of the benefits). They are structural changes which may transform the very nature of the system.

The second wave of reforms of the 2000s

Since the early 2000s, a new wave of reforms is developing in Continental Europe: the 2003 pension reforms and the 2004 Health reforms in France, the Hartz reforms and the 2010 Agenda in Germany, etc. These reforms are not only retrenching social insurance benefits, they contribute to implement structural adaptations that institutional reforms allowed in the first place. In pension, not only are benefits planned to be reduced, but a new basic safety net is implemented in Germany, and fully funded schemes are proposed to German (Riester funds), French (PERP and PERCO), or Italien citizens. In Health, more and more room is given to competition and private actors, through either the Douste Blazy reform or through the 2003 German changes. Activation measures are gaining forces in all the unemployment reforms implemented in France, Gemrany or other continental European countries in the early 2000s (Clegg, XXX). 
The accumulation of these recent institutional and structural changes in social protection plus new employment policies (activation, making work pay) may mean a general paradigmatic change for continental welfare states, evincing a shift from systems aimed at income and status maintenance towards activated and employment friendly welfare systems. All these structural adaptation may appear marginal in the first place. However, the study of the French case shows that if they may appear trivial when introduced, usually being presented as a mere complement to the still central social insurance systems, these policies can develop little by little, to eventually form a veritable 'second world' of welfare within one country (this is the case for the new targeted benefit -RMI or the nex tax - CSG in France, See Palier, 2000). It has become clear that France has now a dual welfare system (Palier, 2002). On the one hand there are 'national solidarity schemes': family benefits, health care and poverty alleviation, delivering either universal or targeted benefits, mainly financed by taxation and controlled by the state. On the other hand, the pensions and unemployment/employment policies have been retained in the social insurance world, even though the meaning of social insurance is changed, becoming more reliant on actuarial and activation principles. Ferrera (1996) has shown that dualization also marked the development of Southern European welfare states.

In terms of explanation, it seems that each type of change need a specific explanation. The first type should probably be understood in terms of path dependency, where government do what they are used to doing, and where institutions really do frame the problems and the type of reforms adopted. We have already presented the type of institutional mechanisms that may explain why Bismarckian welfare systems are difficult to change.

As for the second type of reforms, exogenous forces seems to have played a role, since European constraints and economic crisis seem to have been relevant in explaining why governments in continental Europe decided to change their policies and opt for retrenchment, despite the political cost involved. Contrary to the neglect of the impact of EU on welfare state reforms current welfare state literature (Pierson, 1998, 2001), we hypothesize that European economic policies channel and bind welfare reforms, especially in Bismarckian countries.

Indeed, in several continental welfare states, the timing of the reforms that have been implemented is intriguing. In continental Europe, a first wave of retrenchment reforms in old age insurance, health care insurance and unemployment insurance was concentrated in the first half of the 1990s, during the preparation of the single currency: the Amato (1992) and Dini (1995) pension reforms in Italy, the various pension reforms (during the 1990s), and 1992 Seehoffer Reform of health care in Germany and the 1993 Balladur pension reforms and the 1995 Juppé plan (implemented as far as health insurance is concerned) in France. Moreover, in the early 1990's, certain European countries (Netherlands, Ireland, Denmark, Spain, Itlay) concluded social pacts which included important reforms of part of their welfare states (Rhodes, 2001). It may be that the timing is purely coincidental, but all the above listed reforms were justified by governments as necessary sacrifices to meet the Maastricht criteria. Even though one could argue that these reforms would have been necessary without Maastricht (since the major problems are not linked with Europe, but with domestic developments ${ }^{7}$ ), and that Maastricht was a simple scapegoat allowing governments to avoid blame, it appears that the Maastricht process helped governments, at least rhetorically, to impose reforms otherwise seen as infeasible, especially in the welfare systems of continental Europe. Even if it may be disregarded as being only symbolic, the use of the reference to

\footnotetext{
7 'The available evidence casts doubt on the claim that in the absence of growing economic integration welfare states would be under dramatically less pressure, and national policy-makers markedly more capable of addressing new public demands.' (Pierson, 1998: 541)
} 
Maastricht in the political discourse justifying reforms should be considered as one of the reasons why there has been reforms, instead of nothing at all (Schmidt, 2002). In that sense, to paraphrase Radaelli (2000), EU political, social and economic dynamics became a part of domestic political discourse and public policies in the welfare state field, thus showing that the process of welfare state reforms were at least partially Europeanised ${ }^{8}$.

Moreover, the content of these measures were different form the previous ones. All the aforementioned reforms implied retrenchment in social benefits. The early 1990's were the years when the single currency started to be prepared, and also years of recession. Faced with the recession, the traditional (Keynesian) use of social policies would have been to sustain or even re-boost demand through an increase in social benefits. Here, the reaction was the opposite, imposing cuts in social benefits in a period of economic recession. This reversal has to be linked with the new economic context created by the implementation of the single market and by the preparation of the single currency under Maastricht criteria. The macro-economic policies resulting from economic integration have been influential on the content of welfare state reforms. If Maastricht imposed the timing, it may also have limited the range of responses to welfare state difficulties, or even given a specific general orientation to welfare reforms. As F. Scharpf has demonstrated, changes in the international environment had strong implications for the policy instruments available to governments. European integration is part of these international changes. 'The Maastricht criteria for joining the Monetary Union have practically eliminated deficit spending as a policy tool; and the realisation of the Monetary Union has completely removed monetary policy and exchange rate policy from the control of its member states' (Scharpf, 2000).

As a consequence, increasing social benefits and social contributions (which means increasing labour costs) as a solution to deficits created by temporary reflation policies was much less affordable than before, since it could not be compensated through an adjustment of the exchange rate in order to maintain the competitiveness of national products. The effect seems particularly important for continental welfare states. They are usually referred to as frozen welfare systems since they did not implement important retrenchment during the 1980's. We have seen that instead of nothing, they did something: they dealt with their problem (deficits of social insurance funds) by increasing social contributions. This solution, politically easier than retrenchment in a context where insured salaried people prefer to pay more in order to guarantee a stable level of social protection, appeared to be maladapted in the new economic context. It is only under the constraints imposed by the Maastricht criteria that, in Continental Europe, a change occurred in the policies implemented: instead of increasing social contributions, they started to try to reduce the level of social benefits through the reforms mentioned above.

We think therefore that European constraints partly explain the development of reforms in Bismarckian countries. The European constraint mainly reflects a growing divorce between economic and social policy. Welfare reforms in the late 1990s and in the 2000s can be understood as attempts to reconcile economic and social policies and find new social policies fitting with supply-side economic policies. It appears that this search often leads to new social policies and paradigmatic changes in welfare systems.

In order to understand these kind of reforms and search for innovation and adaptation (mainly the two last type of changes in policy: institutional and structural reforms), one has not only to refer to institutional and exogenous constraints as explanation, but also to the role

\footnotetext{
${ }^{8} \mathrm{C}$ Radaelli argues 'that the concept of Europeanization refers to a set of processes through which the EU political, social and economic dynamics become part of the logic of domestic discourse, identities, political structures and public policies.' (2000: 4)
} 
of ideas and learning processes. Hall's approach is based on processes of policy learning. First type of changes can be understood as the first response which governments may adopt when faced with a difficulty which at this stage is not perceived as a new problem. By only changing the settings of the usual instruments, 'old recipes' are resorted to, repeating what governments are used to do. Hall points out that as a response the first oil shock in the early 1970s, British governments applied 'traditional' Keynesian policies with the aim of boosting demand. Similarly, French governments after the mid 1970s merely did what they were used to doing, i.e. raising social contribution rates in order to finance the growth of social expenditure, rather than reducing social expenditure (Palier, 2000).

However, in something which is progressively perceived as a new context, old recipes produce unintended effects or 'anomalies'. Advised by different kinds of experts (among them, at times, social policy comparativists) governments have become convinced that they need to abandon the previous ways of doing things - which are now perceived to be wrong - and innovate. Two different paths seem available here: the introduction of some innovation which is aimed at preserving the given logic of a system (for example, the so-called 'consolidation' reforms implemented in Germany at the end of the 1980s and during the early 1990s, or the French sectoral reforms, see Palier 2000:122-126) or a change of some of the rules of the game (institutional changes), as well as its goals (paradigmatic shift) in order to adapt the whole system to the new context. Thus, if one wants to understand the political process of changes, one has also to refer to the changes in understandings, perceptions and debates around welfare state during the last 25 years.

\section{Conclusion: Towards a new world of welfare capitalism?}

In order to cope with structural problems, Bismarckian countries have created new benefit programs which follow new logics (means-tested benefits, private funded schemes in pension and health systems), have developed new modes of financing, partly replacing social contributions, and have implemented new management arrangements (privatisation of some administrative tasks, empowerment of the state at the expense of the social partners).

These changes are the result of a process of policy learning. They have been (or will be) implemented only very gradually. Probably because of their marginal scope and because of the fact that they do not directly affect the level of expenditure, few analyses have concentrated on these types of changes, compared with the more common analyses of welfare state change which tend (especially with regard to continental welfare systems) to emphasise path dependency and continuity.

The key question for the future is whether the accumulation of these kind of innovations may mean a structural change in Bismarckian welfare systems, leading to one (or several) new architecture(s), i.e. new principles and new ways of doing, a departure from the traditional "conservative corporatist" way of thinking and doing welfare and a move towards a new world of welfare capitalism. Our reading of the recent comparative literature is that both the liberal and the social democratic worlds of welfare found ways out of the crisis in their own tradition, and did not really need to implement third order changes. In contrast, it would seem such structural change not only necessary in continental European systems, but that it is probably already under way in some countries. 


\begin{tabular}{|c|c|c|c|c|c|}
\hline $\begin{array}{l}\text { Types of } \\
\text { change }\end{array}$ & Context & Diagnosis & $\begin{array}{l}\text { Content of the } \\
\text { policy }\end{array}$ & $\begin{array}{c}\text { Politics of the } \\
\text { reforms }\end{array}$ & Consequences \\
\hline $\begin{array}{c}\text { Before } \\
\text { retrenchemnt }\end{array}$ & $\begin{array}{c}\text { - Economic } \\
\text { downturn } \\
\text { (mid 1970’s } \\
\text { onwards), } \\
\text { - raise in } \\
\text { unemployment, } \\
\text { - social budget } \\
\text { deficits }\end{array}$ & $\begin{array}{l}\text { Social benefits can } \\
\text { help the victims of } \\
\text { the crisis }\end{array}$ & \begin{tabular}{|c|}
$*$ Welfare \\
without work \\
$*$ raise in social \\
contribution \\
$*$ change in the \\
generosity of \\
the benefits
\end{tabular} & $\begin{array}{l}* \text { Applying good old } \\
\text { recipes } \\
\text { * It is easier to raise } \\
\text { social contribution } \\
\text { than taxes, and than } \\
\text { cutting social } \\
\text { benefits }\end{array}$ & $\begin{array}{l}\text { * No big changes of } \\
\text { the welfare state, } \\
\text { frozen landscape } \\
\text { * Increasing } \\
\text { inefficiencies of such } \\
\text { policies (raise in } \\
\text { unemployment, } \\
\text { stagflation) }\end{array}$ \\
\hline $\begin{array}{c}\text { First wave of } \\
\text { Retrenchment } \\
\text { The 1990s }\end{array}$ & $\begin{array}{c}\text {-Economic } \\
\text { recession (early } \\
\text { 1990’s) } \\
\text { - Single market } \\
\text { - Preparation of } \\
\text { the single } \\
\text { currency } \\
\text { - demographic } \\
\text { changes, } \\
\text { - maturation of } \\
\text { the welfare } \\
\text { states }\end{array}$ & $\begin{array}{l}\text { The systems have } \\
\text { to be rescued, } \\
\text { consolidated }\end{array}$ & $\begin{array}{l}* \text { increase in } \\
\text { the } \\
\text { contributivity } \\
\text { of social } \\
\text { insurance } \\
\text { benefits } \\
\text { * tax financing } \\
\text { of non- } \\
\text { contributory } \\
\text { benefits }\end{array}$ & $\begin{array}{l}* \text { Negotiated on the } \\
\text { bases of clarification } \\
\text { between insurance } \\
\text { and } \\
\text { assistance/solidarity }\end{array}$ & $\begin{array}{l}* \text { From social to more } \\
\text { individual insurance } \\
\text { (« erosion of share } \\
\text { fate », Jacob S Hacker) }\end{array}$ \\
\hline $\begin{array}{c}\text { Beyond } \\
\text { retrenchment } \\
\text { Institutional } \\
\text { reforms }\end{array}$ & $\begin{array}{l}\text { - post-industrial } \\
\text { economy } \\
\text { - End of } \\
\text { Keynesianism } \\
\text {-Global and } \\
\text { European } \\
\text { orientation/ } \\
\text { coordination of } \\
\text { economic and } \\
\text { social policies }\end{array}$ & $\begin{array}{l}* \text { Welfare Systems } \\
\text { are partly the cause } \\
\text { of the crisis : work- } \\
\text { based entitlement } \\
\text { re-enforce social } \\
\text { exclusion ; income } \\
\text { maintenance is } \\
\text { disincentive to } \\
\text { work ; } \\
\text { social contribution } \\
\text { damage } \\
\text { competitivity and } \\
\text { create } \\
\text { unempployment ; } \\
\text { corporatist } \\
\text { management rules } \\
\text { hinder reform } \\
\text { capacities }\end{array}$ & \begin{tabular}{|c|}
$*$ * increasing \\
importance of \\
new benefits, \\
(universal or \\
targeted), tax- \\
financed, \\
managed by the \\
State \\
* expansion of \\
private \\
provision \\
* new mode of \\
financing, new \\
taxes, less \\
social \\
contribution \\
* new mode of \\
management \\
(public or \\
private)
\end{tabular} & $\begin{array}{l}\text { * Virus strategy, } \\
\text { layering : } \\
\text { New provision, new } \\
\text { institution are } \\
\text { implemented at a } \\
\text { marginal point, } \\
\text { - on a contradictory } \\
\text { consensus base, - } \\
\text { Then they develop as } \\
\text { to become a second } \\
\text { pillar of the system }\end{array}$ & $\begin{array}{l}\text { Weakening of social } \\
\text { insurances mechanisms } \\
\text { and actors }\end{array}$ \\
\hline $\begin{array}{l}\text { The second } \\
\text { wave of } \\
\text { reforms } \\
\text { Path-breaking } \\
\text { Changes } \\
\text { The 2000s }\end{array}$ & $\begin{array}{c}\text { European Single } \\
\text { market } \\
\text { European } \\
\text { monetary Union }\end{array}$ & $\begin{array}{l}\text { Welfare systems } \\
\text { need a profound } \\
\text { adaptation to the } \\
\text { new economic } \\
\text { context } \\
\text { - Diffusion of the } \\
\text { OECD, EES, OMC } \\
\text { ideas }\end{array}$ & $\begin{array}{l}\text { Multiplication } \\
\text { of pillars in } \\
\text { pension, active } \\
\text { ageing } \\
\text { * Activation of } \\
\text { unemployed } \\
* \text { Competition } \\
\text { in health }\end{array}$ & * Divisive reforms & $\begin{array}{c}* \text { We are all supply- } \\
\text { siders now } \\
\text { * From income } \\
\text { maintenance to } \\
\text { activation, incentives, } \\
\text { employment-friendly } \\
\text { benefits } \\
\text { * Re-commodification } \\
\text { * dualisation of the } \\
\text { systems (social and } \\
\text { private insurance/ } \\
\text { assistance) }\end{array}$ \\
\hline
\end{tabular}


References :

Bonoli, Giuliano, Palier, Bruno (1996) 'Reclaiming Welfare. The Politics of Social Protection Reform in France', in M. Rhodes (ed.) Southern European Welfare states, London: Frank Cass, pp.240-259.

Bonoli, Giuliano, Palier, Bruno (1998) «Changing the politics of social programmes : innovative change in British and French welfare reforms ", Journal of European Social Policy, November, vol.8, n² , pp.317-330.

Bonoli, Giuliano, Palier, Bruno (2000) 'How Do Welfare States Change? Institutions and their Impact on the Politics of Welfare State Reform', European Review, vol. 8, no. 2, pp. 333-352.

Bonoli, Giuliano, (2000) The Politics of Pension Reform. Institutions and Policy Change in Western Europe, Cambridge, Cambridge University Press.

Bonoli, Giuliano (2001) 'Political Institutions, Veto Points, And The Process Of Welfare State Adaptation’ Forthcoming in: P.Pierson (ed.) The New Politics of the Welfare State, Oxford University Press, 314-337.

Esping-Andersen, Gøsta (1990) The three worlds of welfare capitalism, Cambridge, Polity Press.

Esping-Andersen, Gøsta, ed. (1996) Welfare States in Transition. National Adaptions in Global Economies, London, Sage.

Ferrera, Maurizio (1996) "Modèles de solidarité, divergences, convergences: perspectives pour l'Europe”, Swiss Political Science Review, 2, 1: 55-72.

Ferrera, Maurizio (1996b), "The Southern model of welfare in social Europe " in Journal of European Social Policy, volume 6, n²1, pp.17-37.

Ferrera, Maurizio, Rhodes, Martin, eds. (2000) 'Recasting European Welfare States', West European Politics (Special Issue), avril, 23(2).

George, Vic, Taylor-Gooby, Peter, (eds.) (1996) European welfare policy - Squaring the welfare circle, London, Macmillan.

Hall, Peter (1993) «Policy Paradigm, Social learning and the State, the case of Economic Policy in Britain », Comparative Politics, April, pp.275-296.

Hinrichs, Karl (2000) 'Ageing and Public Pension Reforms in Western Europe and North America: Patterns and Politics' paper presented at the conference What Future For Social Security? Cross-National And Multidisciplinary Perspectives organised in Stirling by Jochen Clasen, 15-17 June 2000.

Huber, Evelyne, Stephens, John D. (2001), Political Choice in Global Markets:Development and Crisis of Advanced Welfare States. Chicago: University of Chicago Press.

Kuhnle, Stein, 2000, 'The Scandinavian Welfare State in the 1990's : Challenged but Viable', Ferrera, M., Rhodes, M., eds. (2000) 'Recasting European Welfare States', West European Politics (Special Issue), avril, 23(2), pp.209-228.

Leibfried, Stephan (1993) « Toward a European welfare state ? » in Catherine Jones (ed.) New perspectives on the welfare state in Europe, Londres, Routledge, 1993, pp.133-156.

Leibfried, Stephan, ed. (2000) 'Welfare State Futures', European Review, 8 (2).

Levy, Jonah (1999) 'Vice into virtue? Progressive Politics of Welfare reform in Continental Europe’, Politics and Society, 27, pp.239-273.

Levy, Jonah (2000) 'France: Directing Adjustment?' in Scharpf, Schmidt, vol. 2, pp. 308-350.

Manow, Philip, Seils, Eric (2000) 'Adjusting Badly: The German Welfare State, Structural Change, and the Open Economy’, in Scharpf, Schmidt, vol. 2, pp.264-307. 
Myles, John, Pierson, Paul (1997) «Friedman's Revenge : the Reform of 'Liberal' Welfare States in Canada and the United States », EUI Working Paper RSC N.97/30, Institut Universitaire européen.

Myles, John, Pierson, Paul (2001) 'The Comparative Political Economy of Pension Reform' forthcoming in P. Pierson (ed.) The New Politics of The Welfare State, Oxford: Oxford University Press, forthcoming.

Palier, Bruno (2000) '”Defrosting” the French Welfare State', in Ferrera, M., Rhodes, M., eds. (2000) 'Recasting European Welfare States', West European Politics (Special Issue), avril, 23(2), p.113-136.

Palier, Bruno (2001) 'Reshaping The Social Policy Making Framework : France From The 1980's To 2000 ' in Taylor-Gooby (ed), Welfare states under pressure, London, Sage, forthcoming.

Pierson, Paul (1994) Dismantling the Welfare State? Reagan, Thatcher and The Politics of Retrenchment, Cambridge, Cambridge University Press.

Pierson, Paul (1996) « The New Politics of the Welfare State », World Politics, vol. 48, n¹, janvier, pp.143-179.

Pierson, Paul (1998) 'Irresistible Forces, Immovable Objects: Post-industrial Welfare States Confront Permanent Austerity’ Journal of European Public Policy 5/4.

Pierson, P. (ed) (2001a) The New Politics of the Welfare State, Oxford: Oxford University Press.

Pierson, P. (2001b) Coping with permanent austerity: welfare state restructuring in affluent democracies, in P. Pierson (ed) (2001) The New Politics of the Welfare State, Oxford: Oxford University Press.

Ross, Fiona, 2000, 'Interests and Choice in the 'Not Quite so New' Politics of Welfare’, West European Politics, 23/2, pp.11-34.

Scharpf, Fritz W., Schmidt, Vivien A., eds. (2000) From Vulnerability to competiveness: Welfare and Work in the Open Economy, Oxford, Oxford University Press, 2 volumes.

Visser, Jelle, Hemerijck, Anton (1997) 'A Dutch miracle', Job Growth, Welfare Reform and Corporatism in the Netherlands, Amsterdam, Amsterdam University Press. 